\title{
Evaluation of Marsh seedless grapefruit on ten rootstocks in São Paulo, Brazil
}

Eduardo Sanches Stuchi, Luiz Carlos Donadio, Otávio Ricardo Sempionato, José Antonio Alberto da Silva

Estação Experimental de Citricultura de Bebedouro, PO Box 74,

14700-000 Bebedouro, SP, Brazil

eecb@coopercitrus.com.br
* Correspondence and reprints

Received 18 December 2001 Accepted 13 June 2002

Fruits, 2002, vol. 57, p. 267-272 (C) 2002 Cirad/EDP Sciences All rights reserved DOI: $10.1051 /$ fruits:2002023

RESUMEN EsPAÑoL, p. 272

\section{Evaluation of Marsh seedless grapefruit on ten rootstocks in São Paulo, Brazil.}

Abstract - Introduction. The Brazilian citrus industry is characterized by orange production for processing, with the Rangpur lime (Citrus limonia L. Osbeck) as the predominant rootstock. Grapefruit (Citrus paradisi Macf.) is cultivated on a small scale and represents one of the less studied citrus species. Using other rootstock alternatives to Rangpur lime could increase fruit production and quality. Materials and methods. Ten citrus (Troyer citrange, Swingle citrumelo, Cleopatra mandarin, Valencia Americana sweet orange, Volkamer lemon cv. Catania 2, Nacional and Florida rough lemons, Rangpur lime, Thornton tangelo and trifoliate orange) were evaluated as rootstocks for the Marsh seedless grapefruit in an experiment planted at the Citrus Experimental Station of Bebedouro (EECB), São Paulo State, Brazil, in January 1991. The spacing was $8.0 \mathrm{~m}$ between rows and $4.0 \mathrm{~m}$ between trees. The experimental design, randomized blocks, presented four replications with three trees per plot. Trees were grown without supplementary irrigation. Yield was evaluated from 1994 through 2000; fruit quality from 1994 through 1999; the tree size in May 2000. Results. For each studied characteristic, the various rootstocks showed significant differences, except for the average weight of the fruit. The data obtained were compared with the results already published in the Brazilian literature. Conclusion. Swingle, Troyer, Cleopatra and trifoliate orange could be used as alternative rootstocks for Marsh seedless grapefruit.

Brazil / Citrus paradisi / rootstocks / yields / agronomic characters / fruit / quality

\section{Évaluation du pomelo Marsh seedless greffé sur dix porte-greffes d'agrumes à São Paulo, Brésil.}

Résumé - Introduction. Au Brésil, l'industrie des agrumes est caractérisée par la production d'oranges pour la transformation. Ces arbres sont greffés principalement sur le limetier Rangpur (Citrus limonia L. Osbeck). Le pomelo (Citrus paradisi Macf.) est cultivé sur une petite échelle et représente l'une des espèces d'agrumes les moins étudiées. L'utilisation de porte-greffes différents du limetier Rangpur pourrait permettre d'augmenter la production et la qualité de ces fruits de C. paradisi. Matériel et méthodes. Dix agrumes (citrange Troyer, citrumelo Swingle, mandarinier Cleopatra, oranger Valencia Americana, Volkameriana cv. Catania 2, rough lemons Nacional and Florida, limetier Rangpur, tangelo Thornton et Poncirus trifoliata) ont été évalués comme porte-greffes pour le pomelo Marsh seedless dans un essai planté à la station expérimentale d'agrumes de Bebedouro, état de São Paulo, Brésil, en janvier 1991. L'espacement a été de 8,0 m entre rangées et de 4,0 $\mathrm{m}$ entre arbres. Le dispositif expérimental, en blocs randomisés, a comporté quatre répétitions et trois arbres par parcelle élémentaire. Les arbres se sont développés sans irrigation complémentaire. Le rendement a été évalué de 1994 à 2000 ; la qualité du fruit de 1994 à 1999 ; la dimension des arbres en mai 2000. Résultats et discussion. Pour chacune des caractéristiques étudiées, les divers portegreffes testés ont induit des différences significatives, excepté pour le poids moyen du fruit. Les données obtenues ont été confrontées à des résultats déjà publiés par la littérature brésilienne. Conclusion. Le citrumelo Swingle, le citrange Troyer, le mandarinier Cleopatra et Poncirus trifoliata pourraient être utilisés bénéfiquement en tant que porte-greffes autres que le limetier Rangpur pour le pomelo Marsh seedless.

Brésil / Citrus paradisi / porte greffe / rendement / caractère agronomique / fruit / qualité 


\section{Introduction}

The Brazilian citrus industry is characterized by orange production for processing, with Rangpur lime (Citrus limonia L. Osbeck) as the predominant rootstock.

Grapefruit (Citrus paradisi Macf.) is cultivated on a small scale and represents one of the less studied citrus species. In this case, most of the commercial groves are also based on Rangpur lime rootstock. Almost all fruits produced are destined for processing as frozen concentrated juice, but, recently, grapefruit has been sold in the supermarkets and free markets. These fruits have been imported mainly from the United States and some from Argentina and Uruguay. Grapefruit showed record whole sales in São Paulo State in July, August, and September of 2000. Probably, the consumers of those fruits are among those with higher levels of income, due to their generally high prices, around US\$ $1.3 \mathrm{~kg}$ [1], in the retail. For those reasons the grapefruit can be considered as an alternative crop on a small scale for small producers.

Pompeu Jr. et al. [2] revised the work on scion and rootstock selection done by the Instituto Agronômico de Campinas (IAC, Brazil) from 1952 through 1983, and reported an experiment of rootstocks for the Marsh seedless grapefruit, planted in 1974, in Casa Branca County, SP. The first evaluations indicated Cleopatra mandarin, Swingle citrumelo and Rangpur lime as promising rootstocks. Donadio and Kfouri Filho [3], in Dobrada county, SP, found that the average tree heights and crown diameters of 7-year-old Marsh seedless on Rangpur lime were (3.56 and 3.61) m, respectively. Between the fifth and the seventh year, the yield varied from (70 to 310) fruits.tree ${ }^{-1}$ with an average of 168 fruits tree $^{-1}$. Stuchi [4] reported the yields of the first two crops and the fruit quality of Marsh seedless on Poncirus trifoliata with and without viroid inoculation. The average yield of the not-inoculated plants was (26.6 and 63.23) $\mathrm{kg} \cdot$ tree $^{-1}$, in the first and second crop, respectively. EncisoGaray [5] studied the behavior of six grapefruit clones grafted on Cleopatra mandarin, in Bebedouro, Brazil; four of them were of
Marsh seedless. The author found that the average yield of the Marsh seedless clones in the first four seasons varied between (87.3 and 144) kg.plant ${ }^{-1}$. Fruit quality characteristics of grapefruits produced in Brazil were reported [4-6].

To find the best rootstocks to use with the Marsh seedless grapefruit under the conditions of Bebedouro, São Paulo, Brazil, we studied the vegetative development, yield and fruit quality of Marsh seedless scions grafted on ten rootstocks in that region.

\section{Materials and methods}

The experiment was carried out in the Estação Experimental de Citricultura de Bebedouro (EECB), in Bebedouro county, SP (lat. 2053' 16" S and long. 48 $28^{\prime} 11^{\prime \prime}$ W, $601 \mathrm{~m}$ altitude). The soil was classified as a Haplustox. The climate is of the Cwa according to Koeppen, with average medium maximum and minimum temperatures of (28.8 and 18.3$)^{\circ} \mathrm{C}$ and average temperatures of $23.5^{\circ} \mathrm{C}$; the average annual rainfall is $1522 \mathrm{~mm}$.

The experimental design was randomized blocks, with ten rootstocks as treatments, four replications and three plants per plot. The rootstocks were Troyer citrange (Citrus sinensis (L.) Osbeck $\times$ Poncirus trifoliata (L.) Raf.), Swingle citrumelo (Citrus paradisi $\times$ Poncirus trifoliata (L.) Raf.), Cleopatra mandarin (Citrus reshni Hort. Ex. Tanaka), Valencia Americana sweet orange (Citrus sinensis (L.) Osbeck), Catania 2 lemon (Citrus volkameriana Ten. and Pasq.), Nacional and Florida rough lemons (Citrus jambhiri Lush.), Rangpur lime (Citrus limonia (L.) Osbeck), Thornton tangelo (Citrus reticulata $\times$ Citrus paradisi) and trifoliate orange (Poncirus trifoliata). The spacing was $8 \mathrm{~m}$ between lines and $4 \mathrm{~m}$ between plants ( 312 trees $\cdot \mathrm{ha}^{-1}$ ). The orchard was established in January 1991, without irrigation.

The size of the plants was evaluated in May 2000. The plant height and the scion crown diameter were measured. The height 
was taken from the soil to the top of the plant, and the diameter of the crown was measured in the perpendicular direction of the line of plants. The yield evaluations were done in the years 1994 through 2000 at the following dates: September 05, 1994. August 08, 1995; July 03, 1996; July 08, 1997; June 24, 1998; August 04, 1999 and July 19, 2000: the same time during which there was grapefruit processing for concentrated juice. The average yield was calculated in kg.tree ${ }^{-1}$, every year. Later, the accumulated yield (in kg.tree ${ }^{-1}$ ) was calculated.

Fruit quality was evaluated in the harvesting time from 1994 through 1999 using samples of 10 fruits per plot. Physical and chemical characteristics were determinate such as fruit height, diameter and weight, juice content (\%), total soluble solids (TSS), acidity, and the maturation index or "ratio" plus the technological index (TI $=[$ TSS $\times$ $\%$ juice $\times 40.8] / 10000$ ). For the period from 1994 through 1999, the average data of all characteristics were calculated.

The results were submitted to variance analysis and the averages compared by Tukey test, at the level of $5 \%$ of probability.

\section{Results}

Trees on Thornton and Florida presented the largest average height, differing from those on trifoliate orange, Valencia Americana, Nacional and Rangpur, which induced the smallest tree height. With respect to the average scion crown diameter, Troyer citrange and Florida rough lemon induced the greatest values, and they differed significantly only from Valencia Americana, but not from the other rootstocks. Tree loss, mainly due to Phytophthora spp., was high (66\%) with Valencia Americana rootstock. Tree death occurred in other combinations, due to the same cause (table I).

The values of accumulated yield (kg fruit.tree ${ }^{-1}$ and $\mathrm{kg}$ TSS.tree ${ }^{-1}$ ) and plant yield $\left(\mathrm{kg} \cdot \mathrm{tree}^{-1}\right)$ in the period 1994-2000 showed significant differences in the accumulated yield. Valencia Americana induced the smallest average value, differing from Catania 2 lemon, Florida, Troyer, Swingle and Rangpur, that induced the biggest values (table II).

The average data regarding fruit quality for the period 1994-1999, i.e., the total soluble solids, titratable acidity, juice content, technological index, diameter, height and

\section{Table I.}

Tree height $(m)$, scion crown diameter $(m)$ and tree loss $(\%)$ of Marsh seedless grapefruit on ten citrus rootstocks, 10 years after planting (Bebedouro, Brazil, 2000).

$\begin{array}{lccc}\text { Rootstock } & \begin{array}{c}\text { Tree height } \\ (\mathrm{m})\end{array} & \begin{array}{c}\text { Scion crown diameter } \\ (\mathrm{m})\end{array} & \begin{array}{c}\text { Tree loss } \\ (\%)\end{array} \\ & 4.3 \mathrm{a} & 5.4 \mathrm{ab} & 8 \\ \text { Thornton } & 4.3 \mathrm{a} & 5.6 \mathrm{a} & 0 \\ \text { Florida } & 4.2 \mathrm{ab} & 5.7 \mathrm{a} & 8 \\ \text { Troyer } & 4.1 \mathrm{abc} & 5.4 \mathrm{ab} & 0 \\ \text { Cleopatra } & 3.9 \mathrm{abcd} & 4.9 \mathrm{ab} & 0 \\ \text { Swingle } & 3.8 \mathrm{abcd} & 5.2 \mathrm{ab} & 0 \\ \text { Catania } 2 & 3.6 \mathrm{bcd} & 4.8 \mathrm{ab} & 66 \\ \text { Trifoliate orange } & 3.5 \mathrm{~cd} & 4.3 \mathrm{~b} & 16 \\ \text { Valencia Americana } & 3.5 \mathrm{~cd} & 4.7 \mathrm{ab} & 25 \\ \text { Nacional } & 3.5 \mathrm{~d} & 4.7 \mathrm{ab} & - \\ \text { Rangpur } & & & \end{array}$


fresh mass of the fruits showed significant differences in all of the evaluated characteristics, except for fruit weight (table III). The average fruit weight in all treatments remained in the range of ( 250 to 290 ) g. The largest average diameters of the fruits were induced by Nacional and Florida $(9.0 \mathrm{~cm})$ with significant differences with relation to Swingle and Thornton $(8.6 \mathrm{~cm})$. The highest acidity value was induced by Thornton (1.89\%) which differed from the other treatments, and the lowest was induced by Nacional (1.53\%). The highest TSS value was induced by Swingle (9.45 ${ }^{\circ}$ Brix); Florida, Nacional and Catania 2 induced the smallest values (around $7.3{ }^{\circ}$ Brix) for this characteristic. Swingle induced the highest juice content and Thornton the smallest. For the technological index, the largest value was provided by Swingle $\left(1.73 \mathrm{~kg} \mathrm{TSS} \mathrm{box}^{-1}\right)$ that did not differ significantly from Troyer, Cleopatra and trifoliate orange, all of them with a value of TI of around $1.61 \mathrm{~kg}$ TSS $\cdot$ box $^{-1}$. Florida and Nacional rough lemons and Catania 2 induced values lower than $1.32 \mathrm{~kg}$ TSS $\cdot \mathrm{box}^{-1}$.

\section{Discussion}

The average height and scion crown diameters were $3.91 \mathrm{~m}$ and $5.11 \mathrm{~m}$ (table I), respectively; they are larger than those of Marsh seedless on Rangpur, in a commercial grove, at 7 years of age, evaluated by Donadio and Kfouri Filho [3]. The values reported by the cited authors were of $3.56 \mathrm{~m}$ and $3.61 \mathrm{~m}$, for height and crown diameter, respectively. The average tree height on Rangpur in the experiment was similar to the average height found by the same authors. The average crown diameter was smaller than reported values, for the same combination. The spacing of the experiment $(8.0 \mathrm{~m} \times 4.0 \mathrm{~m})$ can be considered as a good one for the cultivar on all the studied rootstocks. In spite of the fact that some rootstocks have an induced average scion crown diameter larger than the distance between trees in the line, there have been no problems of productivity reduction or of difficulty for the traffic of machines so far.

Table II.

Cumulative yield, total soluble solids (TSS) and average yield of Marsh seedless on ten citrus rootstocks (Bebedouro, Brazil, 1994-2000).

\begin{tabular}{|c|c|c|c|c|}
\hline \multirow[t]{2}{*}{ Rootstock } & \multicolumn{2}{|c|}{ Cumulative yield } & \multicolumn{2}{|c|}{ Average yield } \\
\hline & $\left(\mathrm{kg} \cdot \operatorname{tree}^{-1}\right)$ & $\left(\mathrm{kg}\right.$ TSS $\cdot$ tree $\left.^{-1}\right)$ & $\left(\mathrm{kg} \cdot \mathrm{tree}^{-1}\right)$ & $\left(\mathrm{t} \cdot \mathrm{ha}^{-1}\right)$ \\
\hline Catania 2 & 802.6 a & $24.0^{1}$ & $115^{1}$ & $36^{1}$ \\
\hline Florida & $800.9 a$ & 24.3 & 114 & 36 \\
\hline Troyer & $784.6 \mathrm{a}$ & 31.0 & 112 & 35 \\
\hline Swingle & $771.7 \mathrm{a}$ & 32.7 & 110 & 34 \\
\hline Rangpur & $719.7 a$ & 25.8 & 103 & 32 \\
\hline Nacional & $665.7 \mathrm{ab}$ & 19.9 & 95 & 30 \\
\hline Trifoliate orange & $629.3 a b$ & 24.8 & 90 & 28 \\
\hline Cleopatra & $609.6 \mathrm{ab}$ & 24.1 & 87 & 27 \\
\hline Thornton & $502.2 a b$ & 17.7 & 72 & 22 \\
\hline Valencia Americana & $391.2 \mathrm{~b}$ & 13.9 & 56 & 17 \\
\hline Mean & 667.7 & 23.8 & 95.4 & 29.7 \\
\hline
\end{tabular}


Table III.

Fruit quality characteristics: total soluble solids (TSS), acidity, juice, technological index (TI), diameter, height and weight average values of Marsh seedless on ten citrus rootstocks (Bebedouro, Brazil, 1994-1999).

$\begin{array}{lcllllll}\text { Rootstock } & \begin{array}{c}\text { TI } \\ \left(\mathrm{kg} \mathrm{TSS} \cdot \mathrm{box}^{-1}\right)\end{array} & \begin{array}{c}\text { TSS } \\ \left({ }^{\circ} \text { Brix }\right)\end{array} & \begin{array}{c}\text { Juice } \\ (\%)\end{array} & \begin{array}{c}\text { Acidity } \\ (\%)\end{array} & \begin{array}{c}\text { Height } \\ (\mathrm{cm})\end{array} & \begin{array}{c}\text { Diameter } \\ (\mathrm{cm})\end{array} & \begin{array}{c}\text { Weight } \\ (\mathrm{g})\end{array} \\ \text { Swingle } & 1.73 \mathrm{a} & 9.45 \mathrm{a} & 44.9 \mathrm{a} & 1.74 \mathrm{~b} & 8.1 \mathrm{~b} & 8.6 \mathrm{~b} & 272 \mathrm{a} \\ \text { Troyer } & 1.61 \mathrm{ab} & 9.00 \mathrm{abc} & 44.0 \mathrm{ab} & 1.69 \mathrm{bc} & 8.2 \mathrm{~b} & 8.8 \mathrm{ab} & 280 \mathrm{a} \\ \text { Cleopatra } & 1.61 \mathrm{ab} & 9.02 \mathrm{abc} & 43.7 \mathrm{ab} & 1.74 \mathrm{~b} & 8.3 \mathrm{ab} & 8.8 \mathrm{ab} & 276 \mathrm{a} \\ \text { Trifoliate orange } & 1.61 \mathrm{ab} & 9.12 \mathrm{ab} & 43.4 \mathrm{ab} & 1.72 \mathrm{~b} & 8.2 \mathrm{~b} & 8.8 \mathrm{ab} & 275 \mathrm{a} \\ \text { Rangpur } & 1.46 \mathrm{bc} & 8.31 \mathrm{c} & 43.2 \mathrm{ab} & 1.66 \mathrm{bc} & 8.3 \mathrm{ab} & 9.0 \mathrm{ab} & 281 \mathrm{a} \\ \text { Valencia Americana } & 1.45 \mathrm{bcd} & 8.53 \mathrm{bc} & 42.0 \mathrm{ab} & 1.71 \mathrm{bc} & 8.4 \mathrm{ab} & 8.9 \mathrm{ab} & 271 \mathrm{a} \\ \text { Thornton } & 1.44 \mathrm{bcd} & 8.69 \mathrm{abc} & 40.9 \mathrm{~b} & 1.89 \mathrm{a} & 8.2 \mathrm{ab} & 8.6 \mathrm{~b} & 259 \mathrm{a} \\ \text { Florida } & 1.24 \mathrm{~cd} & 7.38 \mathrm{~d} & 41.3 \mathrm{ab} & 1.67 \mathrm{bc} & 8.5 \mathrm{a} & 9.0 \mathrm{a} & 283 \mathrm{a} \\ \text { Catania 2 } & 1.22 \mathrm{~d} & 7.29 \mathrm{~d} & 41.2 \mathrm{ab} & 1.63 \mathrm{c} & 8.4 \mathrm{ab} & 8.9 \mathrm{ab} & 272 \mathrm{a} \\ \text { Nacional } & 1.22 \mathrm{~d} & 7.33 \mathrm{~d} & 41.2 \mathrm{ab} & 1.53 \mathrm{~d} & 8.5 \mathrm{a} & 9.0 \mathrm{a} & 280 \mathrm{a}\end{array}$

Means followed by the same letter in the column do not differ by Tukey test $(5 \%)$.

In the average of the seven analyzed seasons, Catania 2, Florida, Troyer, Swingle and Rangpur rootstocks induced yields of over $100 \mathrm{~kg} \cdot$ tree $^{-1}$, and could be considered as the most suitable for Marsh seedless. Those values are inferior to those reported by Enciso-Garay [5] for the variety on Cleopatra $\left(115 \mathrm{~kg} \cdot \mathrm{tree}^{-1}\right)$ in the average of the first four crops. Trees on Cleopatra only reached the average of $87 \mathrm{~kg} \cdot$ tree $^{-1}$. The most productive rootstocks showed higher values than the largest average productivity found by Donadio and Kfouri Filho [3], except Rangpur, that presented similar productivity. Figueiredo [6] cited that the productivity of adult plants reaches $200 \mathrm{~kg} \cdot \mathrm{tree}^{-1}$. In the present study, only at the seventh crop (10 years of age), the rootstock Troyer $\left(218 \mathrm{~kg} \cdot \mathrm{tree}^{-1}\right)$ induced a productivity similar to the reported value (data not shown).

The different rootstocks induced variations in the size of the fruits. For the fruit weight, those differences were not significant. In all treatments, the average fruit weight remained within a normal range of values for the variety [(250-290) g], according to other research in Brazil [4-6] and in the lower limit of the range of values found in the wide review of Sinclair [7], ranging from (286 to 466) $\mathrm{g}$.
The largest average diameters of the fruits were induced by Nacional and Florida $(9.0 \mathrm{~cm})$ with significant differences with relation to Swingle and Thornton $(8.6 \mathrm{~cm})$. However, those values can be considered normal because they are close to values reported by some authors $[4,5,7]$.

The average acidity of Marsh seedless juice was reported by Stuchi [4] and EncisoGaray [5] as being of 1.84\% and 1.92\%, respectively. All the rootstocks, except for Thornton, induced lower values of acidity than those reported by the mentioned authors. The highest acidity value was induced by Thornton (1.89\%), which differed from the other treatments, and the lowest was induced by National (1.53\%). The average minimum acidity that we obtained was higher than the values of average acidity found in the literature: 1.3\%, according to Figueiredo [6]; 1.44\%, according to Marchi (unpublished data); and close to the lower limit of the range mentioned by Sinclair [7], that is, ranging from (1.42 to $1.99) \%$.

In relation to the technological index (TI), the largest value was provided by Swingle $\left(1.73 \mathrm{~kg}\right.$ TSS $\cdot$ box $\left.^{-1}\right)$, that did not differ significantly from Troyer, Cleopatra or trifoliate orange, all of them with a value 
of TI of around $1.61 \mathrm{~kg}$ TSS $\cdot \mathrm{box}^{-1}$. The values of TI presented by these rootstocks were close to the average values reported by Enciso-Garay [5] and for Marchi (unpublished data) that are, respectively, (1.78 and 1.60) $\mathrm{kg}$ TSS box $^{-1}$. Florida and Nacional rough lemons and the Catania 2 induced values lower than $1.32 \mathrm{~kg}$ TSS $\cdot \mathrm{box}^{-1}$, which is the minimum value found in the Brazilian literature and reported by Figueiredo [6]. Probably, that fact is due to the smallest values of TSS induced by the three cited rootstocks that were significantly smaller than those induced by the other rootstocks.

The results obtained so far allow us to suggest the use of Swingle, Troyer, Cleopatra and trifoliate orange as alternative rootstocks for Marsh seedless grapefruit in Brazil.

\section{Acknowledgments}

We wish to acknowledge Dr. Francisco de Assis Alves Mourão Filho from University of São Paulo, Piracicaba, Brazil, for his suggestions and detailed review of this article; and thanks to Dimas Alves de Toledo and Luiz Gustavo Parolin, for their helpful assistance with fieldwork.

\section{References}

[1] Anomymous, Grapefruit tem venda recorde na Ceagesp, Folha de São Paulo, São Paulo, Brasil, 3 de outubro de 2000, Agrofolha, p. F3.

[2] Pompeu J. Jr., Figueiredo J.O., Pio R.M., Melhoramento de variedades copas e portaenxertos, Laranja 4 (1983) 305-318.

[3] Donadio L.C., Kfouri Filho E., Seleção de pomeleiros em relação à tristeza dos citros, in: Sociedade Brasileira de Fruticultura (Ed.), An. V Congr. Bras. Frutic., Pelotas, Brasil, 1979, pp. 656-658.

[4] Stuchi E.S., Desenvolvimento vegetativo e produção inicial de pomeleiro Marsh seedless (Citrus paradisi Macf.) enxertado em Poncirus trifoliata (L.) Raf. Inoculado com exocorte, Univ. Estadual Paulista, Jaboticabal, Brasil, Dissertação, 1996, 97 p.

[5] Enciso-Garay C.R., Desenvolvimento vegetativo, produtividade e qualidade dos frutos de seis cultivares de pomeleiro (Citrus paradisi Macf.) enxertados sobre tangerineira Cleópatra (C. resnhi Hort. Ex. Tan.), Univ. Estadual Paulista, Jaboticabal, Brasil, Tese, 1997, $123 \mathrm{p}$.

[6] Figueiredo J.O., Variedades copas, in: Rodriguez O., Pompeu J. Jr., Viegas F.P. (Eds.), Citricultura brasileira, Fund. Cargill, Campinas, Brasil, 1991.

[7] Sinclair W.B., The grapefruit: its composition, physiology, and products, Univ. Calif., Riverside, USA, 1972.

\section{Evaluación del pomelo Marsh Seedless injertado en diez patrones de cítricos en São Paulo, Brasil.}

Resumen - Introducción. En Brasil, la industria de los cítricos se caracteriza por la producción de naranjas para la transformación. Estos árboles se injertan principalmente sobre limero Rangpur (Citrus limonia L. Osbeck). El pomelo (Citrus paradisi Macf.) se cultiva a muy pequeña escala y representa una de las especies de cítricos menos estudiadas. La utilización de patrones distintos del limero Rangpur podría permitir aumentar la producción y la calidad de los frutos de C. paradisi. Material y métodos. Se evaluaron diez cítricos (citrange Troyer, citrumelo Swingle, mandarino Cleopatra, naranjo Valencia Americana, Volkameriana cv. Catania 2, limones rugosos Nacional y Florida, limero Rangpur, tangelo Thornton y Poncirus trifoliata) como patrones para el pomelo Marsh Seedless en un ensayo establecido en la estación experimental de cítricos de Bebedouro, estado de São Paulo (Brasil) en enero de 1991. El espaciado fue de 8,0 m entre hileras y de 4,0 m entre árboles. Se empleó un diseño experimental de bloques aleatorios con cuatro repeticiones y tres árboles por parcela elemental. Los árboles se desarrollaron sin riego complementario. Se evaluó el rendimiento de 1994 a 2000; la calidad de los frutos de 1994 a 1999 y el tamaño de los árboles en mayo de 2000. Resultados y discusión. Excepto en el peso promedio del fruto, los distintos patrones probados indujeron diferencias significativas en cada una de las características estudiadas. Los datos obtenidos se cotejaron con resultados ya publicados por la literatura brasileña. Conclusión. El citrumelo Swingle, el citrange Troyer, el mandarino Cleopatra y Poncirus trifoliata podrían emplearse útilmente como patrones alternativos del limero Rangpur para el pomelo Marsh Seedless.

Brasil / Citrus paradisi / portainjertos / rendimiento / características agronómicas / fruto / calidad 